\title{
Assessment of Knowledge and Practices of Wearing Medical Masks and Respirators during COVID-19 Pandemic
}

\author{
Javaria Saleem, Eelaf Karar, Omer Farooq Choudary, Faiq Munir Shaikh, Rida E Fatima, Farooq Azam Rathore \\ - - - - - - - - - - - - - - - - - - - - - -
} ABSTRACT

Objectives: To determine the gap between knowledge and practices of using face masks and respirators among Pakistani Health care professionals (HCPs) during peak of first wave of COVID-19.

Study Design and Settings: A Cross-sectional online survey of HCPs from different parts of the country was conducted from April-July 2020.

Methodology: A self-administered questionnaire was created using guidelines issued by World Health Organization (WHO) and Centre of Disease Control (CDC) on use of masks and respirators in COVID-19 pandemic. It was distributed via email and social media platforms. Valid responses (402) were analyzed by SPSS V.26. Descriptive statistics and chi square test was applied and p-value $<0.05$ was considered statistically significant.

Results: The knowledge of Pakistani HCPs about masks and respirators was satisfactory but practices were not in line with current guidelines by WHO and CDC. Majority reported that they considered wearing mask/respirators in correct way but only 34\% participants knew all steps of wearing a surgical mask and few knew all steps of wearing an N95 respirator. Concepts like fit test, seal and integrity of mask and respirators, hand hygiene, life of one mask/respirator and their reuse were not clear among most of respondents.

Conclusion: In this diverse sample of Pakistani HCPs, practice of using face masks and respirators was not as per the guidelines despite adequate knowledge. Lack of sufficient practice in using mask and respirators were noticed.

Keywords: COVID-19, Health Care Professionals, N95 Respirators, Pandemic.

How to cite this Article:

Saleem J, Kaarar E, Choudary OF, Shaikh FM, Fatime RE, Rathore FA. Assessment of Knowledge and Practices of Wearing Medical Masks and Respirators during COVID-19 Pandemic. J Bahria Uni Med Dental Coll. 2021; 11(4):158-164 DOI: https://doi.org/ 10.51985/JBUMDC2021010

This is an Open Access article distributed under the terms of the Creative Commons Attribution Non Commercial License (http:// creativecommons/org/licences/by-nc/4.0) which permits unrestricted non commercial use, distribution and reproduction in any medium, provided the original work is properly cited.

\section{INTRODUCTION:}

The novel corona virus (COVID-19) infection originated from Wuhan city, China in December 2019 and rapidly

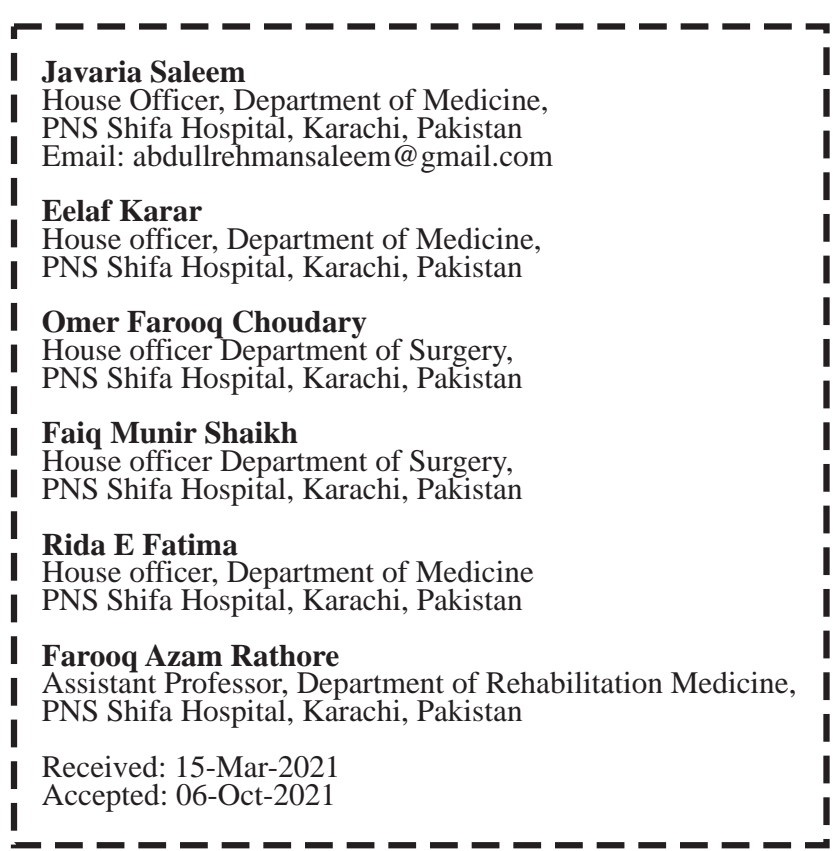
spread to more than 200 countries around the globe over the next 4 months. World Health Organization (WHO) declared it a pandemic on $11^{\text {th }}$ March 2020. ${ }^{1,2}$

WHO has issued guidelines regarding protective measures in order to prevent further transmission of COVID-19. Personal Protective Equipment (PPE) is recommended for Health care professionals (HCPs). The type of PPE depends on settings, target personnel and activity. The use of PPE must be combined with proper hand hygiene, respiratory hygiene, and adequate training on donning, doffing and disposal of the PPE. ${ }^{3}$ Other important measures include hand hygiene and avoiding the entry of the virus through mouth, nose and eyes by avoiding touching these areas. ${ }^{4}$

WHO advised face masks for protection of HCPs, however, incorrect use reduces their effectiveness and makes one prone to getting infected. Hence, adequate knowledge among HCPs is necessary for their protection. ${ }^{5}$ Lack of knowledge not only reduce the effectiveness of the protective barriers worn but also give a false sense of security to one, making them more vulnerable to infection. In July 2020, it was reported by a local newspaper that as many as 5367 healthcare professionals were diagnosed with COVID-19 in Pakistan out of which 58 had died. ${ }^{6}$ Since the only way to control the 
infection is through non-pharmacological methods like use of masks and other PPE combined with hand hygiene. Hence, the knowledge and practice is critical and must be satisfactory among HCPs because they are the high risk group. If the cases among HCPs rise further, it will put even more burden on the healthcare system of Pakistan.

Use of face masks by general population specially in crowded and public spaces helps to reduce the spread of virus in epidemic areas. ${ }^{7,8}$ Face masks are the commonest PPE used both by public and HCPs. However, few HCPs were using them before the pandemic but now they are widely used. However, there are concerns regarding proper selection, fitting, and disposal of masks. Incorrect use of medical masks, including re-using one time use disposable masks or incorrectly putting on an N95 respirator or adjusting it due to discomfort can reduce its protective effect as well increase chances of infections. ${ }^{1,9}$

Few studies address correct use of masks and respirators and most of them are from Europe and the Western countries. A study on HCPs from major public hospital in Karachi assessed masks wearing during the current pandemic revealed gaps in knowledge of HCPs. ${ }^{10}$ Many respondents (43.6\%) were not sure of which side of surgical mask should face outwards. A large number of respondents $(70.9 \%)$ believed that wearing a surgical mask will protect them from COVID19. The study concluded that "overall results" were good and only $35.2 \%$ respondents fell into that category. The study focused mainly on the knowledge and practices of surgical mask use. ${ }^{10}$ To explore it further and evaluate actual practices and knowledge of use of surgical mask as well as respirators in a larger sample of HCPs. This study was aimed to document knowledge and practices of a wide range of masks and respirators used among Pakistani HCPs.

\section{METHODOLOGY:}

A nationwide cross-sectional survey to assess knowledge and practices of Pakistani HCPs regarding masks was conducted from $15^{\text {th }}$ April-10 $0^{\text {th }}$ July 2020. Approval of hospital ethics review committee was obtained before commencing the study. An English language selfadministered questionnaire was created after literature search and consulting guidelines issued by WHO and Centers for Disease Control and Prevention (CDC), USA. ${ }^{5}$ It was pilot tested and revised based on the feedback of the respondents.

The questionnaire was created using Google forms, (a free and powerful online software commonly used for online surveys), consisting of 25 items and 4 sections. ${ }^{11}$ First part was informed consent which explained aim of the study and ensured anonymity of participants. Second part consisted of demographics including age, gender, province of residence and job designation. The third section documented knowledge by asking 6 questions regarding use of masks and respirators and the last section assessed practices of wearing masks. The assessment of practices was done by asking a series of questions regarding different kinds of masks and inquiring about the steps that they followed while wearing and removing surgical masks and N95 respirators. These questions were based on the recommendations of CDC and WHO. ${ }^{12,13}$ The questions on the steps of wearing the mask and respirator were optional so respondents could answer about the masks and/or respirator that they wore most of the time in their medical practice. However, steps of removal were similar in both surgical and N95 Respirators therefore, this question was mandatory for all respondents. The sample size was calculated by using WHO sample size calculator. Considering $5 \%$ precision, with a $95 \%$ confidence interval, and prevalence taken as $56.4 \%$ of HCPs correctly knowing how to wear a mask. ${ }^{10}$ Sample size was calculated as 378 by keeping margin of $10 \%$ for invalid responses and aimed for 400 responses.

Estimated time for completing the questionnaire was 8-10 minutes. The questionnaire was emailed and sent via Social Media applications to HCPs from different background all around the country. Participants included physicians, paramedical staff (PMS), and Allied Health care Professionals (AHCPs) all around the country. Incomplete questionnaires and other professional were excluded from the study. The HCPs working at the hospital of researchers were approached in person and asked to fill in the questionnaire online using a tablet. All HCPs were categorized into groups on the basis of their job hierarchy and their knowledge and practices were compared. The data was analyzed using SPSS version 26.0. Frequencies and descriptive statistics were calculated and Pearson's Chi square test was applied p-value $<0.05$ was considered significant.

\section{RESULTS:}

Total four hundred and six health care professionals participated in the study and 402 were valid responses. The demographics are displayed in Table 1 . The mean age was $30.92( \pm 9.16)$ and range was $20-72$ years. Total one hundred and forty eight $(36.7 \%)$ respondents had a contact with confirmed COVID-19 patients. Around one third (29.1\%) regularly wore mask in hospital before this pandemic. However, after the pandemic $345(85.8 \%)$ respondents wore a mask daily. Around nineteen (4.7\%) respondents still did not wear a mask at all. Out of the $386(96.0 \%)$ HCPs who wore masks, $(67.4 \%) 271$ wore a surgical mask, and (12.2\%) 49 wore N95/N99 respirator and (18.2\%) 66 used a combination of masks with surgical mask being the most used one.

Knowledge about the general use of mask and respirators was overall adequate among all the groups of HCPs (Table 2), except for the knowledge about the type of mask a patient with active COVID-19 infection should wear only $28.4 \%$ (114) knew COVID-19 patient should wear surgical mask. This knowledge was found to be inadequate in all the groups of health care professionals ( $\mathrm{p}$-value $=0.086$ ). When questioned the need for N95 respirator use among the general 
Javaria Saleem, Eelaf Karar, Omer Farooq Choudary, Faiq Munir Shaikh, Rida E Fatima, Farooq Azam Rathore

Table 1 Demographics

\begin{tabular}{|c|c|}
\hline Parameters & Total Number $=402(\%)$ \\
\hline Age & 20- 72 Mean age $30.92( \pm 9.16)$ \\
\hline \multicolumn{2}{|l|}{ Gender } \\
\hline Male & $182(45.3 \%)$ \\
\hline Female & $220(54.7 \%)$ \\
\hline \multicolumn{2}{|l|}{ Education } \\
\hline Matriculation & $3(0.7 \%)$ \\
\hline Intermediate & $20(5.0 \%)$ \\
\hline Under graduate & $10(2.5 \%)$ \\
\hline Graduate & $197(49.0 \%)$ \\
\hline Post-graduate & $172(42.8 \%)$ \\
\hline \multicolumn{2}{|l|}{ Residence } \\
\hline Sindh & $255(63.4 \%)$ \\
\hline Punjab & $113(28.1 \%)$ \\
\hline Baluchistan & $8(2.0 \%)$ \\
\hline KPK & $14(3.5 \%)$ \\
\hline Gilgit-baltistan & $9(2.2 \%)$ \\
\hline Kashmir & $3(0.7 \%)$ \\
\hline \multicolumn{2}{|l|}{ Job status } \\
\hline House Officers & $119(29.6 \%)$ \\
\hline Residents & $90(22.4 \%)$ \\
\hline Consultants & $88(21.9 \%)$ \\
\hline $\begin{array}{l}\text { Para medical staff (including } \\
\text { nursing, midwifes, sanitation, } \\
\text { pharmacy, physiotherapy } \\
\text { assistants, laboratory technicians) }\end{array}$ & $63(15.6 \%)$ \\
\hline $\begin{array}{l}\text { Allied health professionals } \\
\text { (including dental hygienists, } \\
\text { diagnostic medical sonographers, } \\
\text { dieticians, medical technologists, } \\
\text { occupational therapists, physical } \\
\text { therapists, radiographers, } \\
\text { respiratory therapists, and speech } \\
\text { language pathologists) }\end{array}$ & $23(5.7 \%)$ \\
\hline Medical Officers & $19(4.7 \%)$ \\
\hline
\end{tabular}

public, most of the respondents knew that it was not meant for public use (p-value $<0.05)$.

About $81.6 \%$ (328) participants indicated that that they wore their mask in a correct way, while $16.9 \%$ were not sure of their way. However, when their knowledge and practice of wearing N95/N99 respirator and surgical mask was evaluated only $14.8 \%$ knew all the steps of wearing a respirator scoring $9 / 9(\mathrm{p}$-value $=0.016)$ and $34 \%$ knew all the steps of wearing a surgical mask scoring 6/6 (p-value $=0.002)$. A quarter $(25 \%)$ of respondents followed all the steps in removal of a mask (p-value= 0.039). (Table 2)

Questions evaluating the practice of respondents of donning and doffing the mask and respirators are listed in table 3. Only $62.5 \%$ people performed the fit test before wearing respirator, $56.8 \%$ people checked its integrity before wearing it, $71.6 \%$ performed hand hygiene before wearing a mask, $44.3 \%$ respondent checked the seal by blow test after wearing it and only $20.4 \%$ people know that in people with facial hair it is not ideal to wear N95/N99 respirator as it doesn't create an efficient seal. (Table 3 ) Around $62 \%$ respondents wore a mask in a way that the bendy nose strip went on bridge of the nose. Around half (54.23\%) of the respondents did not know the correct way to store/dispose a mask or respirator when not in use. Out of 402 respondents 211 $(52.5 \%)$ HCPs were reusing their surgical masks, when inquired about the reason most HCPs responded with the reason of limited availability.

\section{DISCUSSION:}

Our study found that surgical masks were the most common form of masks used by HCPs irrespective of their contact with COVID-19 patients. Those who had contact with COVID-19 patients reported more usage of respirators. WHO recommends that a medical mask should be worn in areas with patients suspected or having a confirmed diagnosis of COVID-19 and an N95 respirator wherever aerosol is being generated. ${ }^{5}$ Since the cost of an N95 is more than surgical mask it is not always practical and cost effective to wear N95 respirator unnecessarily. ${ }^{14}$

WHO recommends that proper hand hygiene must be combined with use of face masks among HCPs. ${ }^{5}$ However respondents having lower education believed that the risk of infection was completely eliminated by a well fitted respirator and therefore hand hygiene was not needed ( $p$ value $<0.001$ ). This is an alarming fact ignoring the hygiene and making them vulnerable to infections. This points out that training emphasis should me more towards low educated HCPs.

Previous studies have suggested that use of surgical masks is helpful in preventing transmission of human coronavirus virus infections if worn by infected persons yet most of the respondents were not aware that a patient of COVID-19 must wear a surgical mask and not an N95 respirator (pvalue $=0.052) .{ }^{15,16}$ Literature suggests that an N95 respirator is not more effective than a surgical face mask in protecting HCPs from acute respiratory infections in hospital setting. ${ }^{9}$ But most $(92.8 \%)$ of the respondents in our study responded that N95 respirator was more protective than a surgical mask and very few $(7.2 \%)$ responded that N95 and surgical masks had equal efficacy ( $\mathrm{p}$-value $=0.769)$.

Only $71.9 \%$ of the respondents understood that they need to cover their mouths while sneezing and coughing despite wearing a mask. This is because surgical masks are a barrier for droplets not for aerosol particles and viruses can still cross the barrier. ${ }^{17}$ This practice was not adequately followed among Residents/Trainees ( $\mathrm{p}$-value $=0.330$ ). Lack of this knowledge can potentially lead to spread of virus and cause devastating increase in infected people even though all SOPs are followed. ${ }^{17}$

Around $62.96 \%$ respondents wore a mask in a way that the bendy nose strip went on bridge of the nose on the contrary 
Assessment of Knowledge and Practices of Wearing Medical Masks and Respirators during COVID-19 Pandemic

Table 2 Knowledge and practice regarding use of mask and respirator according to job status of HCPs

KNOWLEDGE

\begin{tabular}{|c|c|c|c|c|c|c|c|}
\hline \multirow[t]{2}{*}{ Statements } & $\begin{array}{l}\text { House } \\
\text { officer }\end{array}$ & Residents & Consultant & $\begin{array}{c}\text { Medical } \\
\text { officer/ RMO }\end{array}$ & $\begin{array}{l}\text { Para medical } \\
\text { staff }\end{array}$ & $\begin{array}{l}\text { Allied health } \\
\text { professionals }\end{array}$ & \multirow[t]{2}{*}{$P$ value } \\
\hline & $\mathrm{N}(\%)$ & $\mathrm{N}(\%)$ & $\mathrm{N}(\%)$ & $\mathrm{N}(\%)$ & $\mathrm{N}(\%)$ & $\mathrm{N}(\%)$ & \\
\hline $\begin{array}{l}\text { Does a surgical mask help in reducing } \\
\text { exposure of your saliva and } \\
\text { respiratory droplets? (Yes) }\end{array}$ & $114(95.7 \%)$ & $82(91.1 \%)$ & $82(93.1 \%)$ & $18(94.7 \%)$ & $56(88.8 \%)$ & $23(100 \%)$ & 0.353 \\
\hline $\begin{array}{l}\text { Surgical mask should not be shared } \\
\text { or reused? (Yes) }\end{array}$ & $115(96.6 \%)$ & $88(97.7 \%)$ & $87(98.8 \%)$ & $19(100 \%)$ & $63(100 \%)$ & $23(100 \%)$ & 0.550 \\
\hline $\begin{array}{l}\text { Do you think a properly fitted N95 } \\
\text { or N99 respirator does not completely } \\
\text { eliminate the risk of infection so it } \\
\text { should be accompanied by hand and } \\
\text { personal hygiene? (Yes) }\end{array}$ & $104(87.3 \%)$ & $84(93.3 \%)$ & $85(96.5 \%)$ & $19(100 \%)$ & $57(90.4 \%)$ & $23(100 \%)$ & 0.062 \\
\hline $\begin{array}{l}\text { What type of mask should a COVID- } \\
19 \text { patient wear? (surgical) }\end{array}$ & $30(25.2 \%)$ & $20(22.2 \%)$ & $34(38.6 \%)$ & $5(56.3 \%)$ & $18(28.5 \%)$ & $7(30.4 \%)$ & 0.086 \\
\hline
\end{tabular}

\section{PRACTICE}

\begin{tabular}{|l|c|c|c|c|c|c|c|}
\hline \multirow{2}{*}{ Statements } & $\begin{array}{c}\text { House } \\
\text { officer }\end{array}$ & Residents & Consultant & $\begin{array}{c}\text { Medical } \\
\text { officer/ RMO }\end{array}$ & $\begin{array}{c}\text { Para medical } \\
\text { staff }\end{array}$ & $\begin{array}{c}\text { Allied health } \\
\text { professionals }\end{array}$ & P value \\
\cline { 3 - 8 } & $\begin{array}{c}\text { N out of } \\
26(\%)\end{array}$ & $\begin{array}{c}\text { N out of } \\
29(\%)\end{array}$ & $\begin{array}{c}\text { N out of } \\
17(\%)\end{array}$ & $\begin{array}{c}\text { N out of } \\
4(\%)\end{array}$ & $\begin{array}{c}\text { N out of } \\
10(\%)\end{array}$ & $\begin{array}{c}\text { N out of } \\
2(\%)\end{array}$ & $2(100 \%)$ \\
\hline $\begin{array}{l}\text { While wearing an N95 } \\
\text { or N99 respirator what } \\
\text { steps out of following } \\
\text { do you follow? }\end{array}$ & $0-3$ (poor) & $5(19.3 \%)$ & $9(31.0 \%)$ & $3(17.6 \%)$ & $2(50 \%)$ & $7(70 \%)$ & 0 \\
\hline
\end{tabular}

to a previous study that showed $93 \%$ of HCPs knew this correctly. ${ }^{10} \mathrm{CDC}$ recommends this as metal strip improves the fit and filtration of surgical mask, ${ }^{18}$ Even a correctly worn surgical masks is more effective than an N95 respirator even when respirators provide a better seal and fit. ${ }^{19}$

Most $81.6 \%$ of people were sure that they wore their masks correctly, However only $14.8 \%$ of those respondents who answered that they knew all the steps in wearing an N95 respirator, actually had a satisfactory practice. And $68 \%$ of those respondents who answered that they knew all the steps in wearing a surgical mask and actually had a satisfactory practice. Similar lack of practice was documented by a study in Hong Kong on general public about knowledge and practice of mask where $88.5 \%$ respondents had this perception and only $52.0 \% \hat{\mathrm{E}}$ correct answers. ${ }^{17}$ This drastic difference of knowledge and practice in may be due to the reason that masks and respirators have a simple design and HCPs can assume they know the its correct method of donning, doffing and use. The lack of knowledge about the correct steps and inadequacy to follow them may also be secondary to absence of instructions on packaging of masks and respirators. In most countries manufacturers have no guidelines on the packaging for masks and respirators to follow. Also designs, colours, types, size differ manufacturer to manufacturer and lack proper of knowledge and instructions make it difficult to wear mask and respirator properly. ${ }^{17}$

Previous study showed that, $80 \%$ of HCPs were aware that fit test should be done while using an N95 respirator. ${ }^{20}$ But only $56.8 \%$ of HCPs in our study performed it while donning a respirator. Similarly our study shows $79.5 \%$ HCPs did not know that in people with facial hair it is not ideal to wear N95/N99 respirator as it doesn't create an efficient seal. ${ }^{21}$ Without the fit test it is not known whether or not a seal is created and without a seal the efficacy of N95 to minimise transmission of infection is reduced. ${ }^{22,23}$ This reveals that although people perceived that they are wearing their masks 
Javaria Saleem, Eelaf Karar, Omer Farooq Choudary, Faiq Munir Shaikh, Rida E Fatima, Farooq Azam Rathore

Table 3 Steps of Practices followed By HCPs for Wearing and Removing Mask or a Respirator

\begin{tabular}{|c|c|}
\hline Steps of wearing an N95 Respirator & $\begin{array}{l}\text { N Out Of } 88 \\
\text { Who follow the steps } \\
\text { \% }\end{array}$ \\
\hline Making sure the mask is fit tested for you and you have correct size for your face. & $55(62.5 \%)$ \\
\hline Check its integrity and the elastic bands. & $50(56.8 \%)$ \\
\hline Clean your hands with soap and water or hand sanitizer. & $68(77.3 \%)$ \\
\hline Hold mask over your nose and mouth with the nose clip facing top with the dominant hand. & $63(71.6 \%)$ \\
\hline Holding the top strap and placing it over the crown of your head. & $54(61.4 \%)$ \\
\hline Holding the bottom strap and placing it over the base of your neck. & $53(60.2 \%)$ \\
\hline Pinch the nose strip with both hands to mold to the shape of your nose. & $54(61.4 \%)$ \\
\hline Perform the air test (blowing air into your mask and checking if air escapes through the sides). & $39(44.3 \%)$ \\
\hline Making sure person using N95 or N99 respirator does not have any facial hair. & $18(20.5 \%)$ \\
\hline Steps of wearing a surgical mask & $\begin{array}{l}\text { N Out Of } 388 \\
\text { Who follow the steps } \\
\text { \% }\end{array}$ \\
\hline Clean your hands with soap and water, or hand sanitizer. & $287(73.97 \%)$ \\
\hline Hold mask in a way that stiff bendable strip is on top. & $244(62.89 \%)$ \\
\hline Secure mask over your nose and mouth by its band or loops. & $254(65.46 \%)$ \\
\hline Pinch the nose strip to mold to the shape of your nose. & $264(68.04 \%)$ \\
\hline Pull the top and bottom of the surgical mask over your mouth and chin. & $233(60.5 \%)$ \\
\hline There should be no gap in between the skin and mask to allow unfiltered air to pass through. & $208(53.61 \%)$ \\
\hline Steps of removing a mask & $\begin{array}{l}\text { N Out Of } \mathbf{4 0 2} \\
\text { Who follow the steps } \\
\text { \% }\end{array}$ \\
\hline Avoid touching front of the mask. & $257(63.93 \%)$ \\
\hline Clean your hands with soap and water, or hand sanitizer, before touching the mask. & $193(48.01 \%)$ \\
\hline Remove mask by holding the loops/bands/elastic. & $310(77.11 \%)$ \\
\hline $\begin{array}{l}\text { Dispose of the mask in the trash bin designated for infected waste/yellow bins. (Not keeping it below } \\
\text { your chin or in your pocket when not in use). }\end{array}$ & $218(54.23 \%)$ \\
\hline Clean your hands with soap and water, or hand sanitizer again, before touching anything else. & $250(62.19 \%)$ \\
\hline Practice & $\begin{array}{l}\text { N Out Of } \mathbf{4 0 2} \\
\text { Who follow the steps } \\
\text { \% }\end{array}$ \\
\hline Do you cover your mouth and nose while sneezing or coughing even while w & $289(71.89 \%)$ \\
\hline
\end{tabular}

correctly, in reality they are not. (Table 3)

Regarding overall practice, the best practice is among the consultants, then house officers. Residents and paramedic staff had a similar practice. AHCPs have quite poor practice despite their good knowledge. This shows that HCPs do know sufficiently about the use of masks but when it comes to practically using one, they lack expertise. (Table 2)

Regarding comparison of level of education to practice, it can be concluded that the practice was best among postgraduate group overall yet still unsatisfactory. Matriculation group had very poor practice; this tells us there is more lack of training and teaching among those HCPs do not possess any higher education ( $\mathrm{p}$-value>0.05).

It can be concluded that consultants had the good practice regarding wearing an N95 respirator and surgical mask whereas PMS had the poorest practice. (Table 2)
During the initial days of COVID-19 there was a global shortage of masks, and patients and $\mathrm{HCW}$ were forced to reuse one time use disposable masks. ${ }^{22}$ This is a unanimous observation that led us to include a question regarding the reuse of disposable surgical masks. Although, $98.3 \%$ of the respondents knew that the masks cannot be reused or shared, still $52.5 \%$ of them reported reusing the single use surgical masks. The main reason given by most was limited availability of mask and respirators. Similar practice was pointed out in a previous study that $20.2 \%$ HCPs reused their mask. ${ }^{10}$ This shows that the availability of PPE for HCPs is limited in hospitals, forcing them to reuse surgical masks. This is similar to other reports. ${ }^{22}$

In the pre-COVID times, masks and specially N95 respirators were not used routinely even in hospitals. Therefore, the knowledge and practice about their use are inadequate. In order to improve the practice and knowledge among HCPs, 
education and training through social media, print media, televisions, videos, virtual workshops and demonstrative workshops must be done along with their regular and repetitive reinforcement as mentioned in previous studies conducted in Pakistan. ${ }^{22,24,25}$ As a previous study of Pakistan shows that only $58 \%$ of HCPs have institutional and departmental guidelines and $70 \%$ use online resources for knowledge. ${ }^{22}$ Hence, mediums like social media, print media, virtual workshops and various online resources can be used to educate HCPs and public about the disease and prevention.

The strength of the study included a comprehensive questionnaire, diversity of respondents and a relatively larger sample of HCPs. However, considering the total number of HCPs in Pakistan, 402 appear to be a small sample size. In addition, there were very few respondents from Baluchistan, Kashmir and Gilgit-Baltistan.

\section{CONCLUSION:}

Knowledge of Pakistani HCPs about masks and respirators was satisfactory but the practice of wearing and removing is poor and not in line with the current guidelines by WHO and CDC. Majority HCPs reported that they considered wearing mask/respirators in correct way but in reality; only one third of participants knew all the steps of wearing a surgical mask and a few knew all the steps of wearing an N95 respirator. Concepts like fit test, seal and integrity of the mask and respirators, hand hygiene, life of one mask/respirator and their reuse were not clear to most of the respondents. We recommend that masks and other PPE must be available to HCPs at all times to ensure their safety and to avoid cross contamination between vulnerable patients. Moreover every person working in the hospital should be trained in the correct ways of donning, doffing and disposal of PPE.

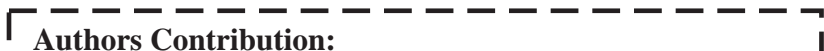
Javaria Saleem: Drafting of the work and Final approval of
the version to be published

Eelaf Karar: Drafting of the work and Final approval of the I version to be published

| Omer Farooq Choudary: Interpretation of data and Final | approval of the version to be published

I Faiq Munir Shaikh: Conception or design of the work; or the acquisition, analysis, or interpretation of data for the work and I

Final approval of the version to be published

I Rida E Fatima: Conception or design of the work; or the

acquisition, analysis, or interpretation of data for the work and

Final approval of the version to be published

I Farooq Azam Rathore: Drafting of the work and Final approval I of the version to be published

\section{REFERNCES:}

1. Feng S, Shen C, Xia N, Song W, Fan M, Cowling BJ. Rational use of face masks in the COVID-19 pandemic. Lancet Respir Med. 2020;8(5):434-436. DOI: https://doi.org/10.1016/S22132600 (20) 30134-X.

2. World Health Organization. Coronavirus (COVID-19) outbreak [Internet] 2020 [cited 2020 may 23]. Available from: https://www.who.int/westernpacific/emergencies/covid-19
3. World Health Organization. Rational use of personal protective equipment for coronavirus disease (COVID-19): interim guidance, 2020 [Internet] 2020 [cited 2020 may 20]. Available from: https://apps.who.int/iris/handle/10665/331215

4. Güner R, Hasanoðlu I, Aktap F. COVID-19: Prevention and control measures in community. Turk J Med Sci. 2020;50(SI1):571-577. DOI: https://doi.org/10.3906/sag-2004-146.

5. World Health Organization. Advice on the use of masks in the context of COVID-19: interim guidance, 2020. [Internet] 2020 [cited 2020 June 23]. Available from:https://apps. who.int/iris/handle/10665/332293

6. Bhatti MW. Pakistan has lost 42 doctors among 58 healthcare providers to COVID-19. International The News 2020 [Internet]. 2020 [cited 2020 junly 16]. Available from:https://www.thenews.com.pk/print/680655-pakistanhas-lost-42-doctors-among-58-healthcare-providers-to-covid19

7. Liang T. Handbook of COVID-19 prevention and treatment. The First Affiliated Hospital, Zhejiang University School of Medicine. Compiled According to Clinical Experience. 2020;68.

8. Centers for Disease Control and Prevention (CDC) (2020). Coronavirus Disease 2019 (COVID-19).2021 [Internet] 2021[cited 2021 may 20]. Available from: https://www.cdc.gov /coronavirus/2019-ncov/hcp/infection-controlrecommendations.html

9. Smith JD, MacDougall CC, Johnstone J, Copes RA, Schwartz B, Garber GE. Effectiveness of N95 respirators versus surgical masks in protecting health care workers from acute respiratory infection: a systematic review and meta-analysis. CMAJ. 2016;188(8):567-574. DOI: https://doi.org/10.1503/ cmaj. 150835 .

10. Kumar J,Katto M, Siddiqui A A, et al.Knowledge, Attitude, and Practices of Healthcare Workers Regarding the Use of Face Mask to Limit the Spread of the New Coronavirus Disease (COVID-19). Cureus. 2020;12(4): e7737. doi:10.7759/cureus.7737

11. Edelmayer S. 09 Awesome Reasons to Use Google Forms [Internet] 2020 [cited 2020 April 14]. Available from:https://www.makeuseof.com/tag/5-awesome-reasonsto-use-google-forms/

12. Centre of disease control. Ebola (Ebola Virus Disease) [Internet] 2020 [cited 2020 may 9]. Available from: https://www.cdc.gov/vhf/ebola/healthcare-us/ppe/training.html

13. World Health Organization. Coronavirus disease (COVID19) advice for the public: When and how to use masks [Internet] 2020 [cited 2020 may 10]. Available from:https: //www.who.int/emergencies/diseases/novel-coronavirus2019/advice-for-public/when-and-how-to-use-masks.

14. Cowling BJ, Zhou Y, Ip DK, Leung GM, Aiello AE. Face masks to prevent transmission of influenza virus: a systematic review. Epidemiol Infect. 2010;138(4):449-56. DOI: https://doi.org/ 10.1017/S0950268809991658.

15. The Department of Health, Hong Kong. Guidelines on prevention of coronavirus disease 2019 (COVID-19) for the general public. [Internet] 2020 [cited 2020 may 10]. Available from:https://www.chp.gov.hk/files/pdf/nid_guideline_gener al_public_en.pdf 
16. Leung NHL, Chu DKW, Shiu EYC, Chan KH, McDevitt JJ, Hau BJP, Yen HL, Li Y, Ip DKM, Peiris JSM, Seto WH, Leung GM, Milton DK, Cowling BJ. Respiratory virus shedding in exhaled breath and efficacy of face masks. Nat Med. 2020 (5):676-680. DOI: https://doi.org/ 10.1038/s41591020-0843-2.

17. Ho HS. Use of face masks in a primary care outpatient setting in Hong Kong: Knowledge, attitudes and practices. $\mathrm{Pu} \mathrm{He}$. 2012;126(12):1001-6. DOI: https://doi.org/ 10.1016/ j.puhe.2012.09.010.

18. Centre of disease control. Improve the Fit and Filtration of Your Mask to Reduce the Spread of COVID-19 [Internet] 2021 [cited 2021 July 10]. Available from: https://www.cdc.gov/coronavirus/2019-ncov/prevent-gettingsick/mask-fit-and-filtration.html

19. Noti JD, Lindsley WG, Blachere FM, Cao G, Kashon ML, Thewlis RE, McMillen CM, King WP, Szalajda JV, Beezhold $\mathrm{DH}$. Detection of infectious influenza virus in cough aerosols generated in a simulated patient examination room. Clin Infect Dis. 2012;54(11):1569-77. DOI: https://doi.org/ 10.1093/ $\mathrm{cid} / \mathrm{cis} 237$.

20. Haq MI, Shafiq F, Sheikh H. Potential barriers amongst health care professionals of Pakistan in managing COVID-19 patients. Pak J Med Sci. 2020; 36(COVID19-S4): S17-S21. DOI: https://doi.org/ 10.12669/pjms.36.COVID19-S4.2753
21. Muñoz-Leyva F, Niazi AU. Common breaches in biosafety during donning and doffing of protective personal equipment used in the care of COVID-19 patients. Can J Anaesth. 2020;67(7):900-901. DOI: https://doi.org/ 10.1007/s12630020-01648-x.

22. Provincial Infectious Diseases Advisory Committee. Routine practices and additional precautions in all health care settings.[Internet] 2009 [cited 2020 June 2]. Available from: http://www. publichealthontario. ca/en/eRepository /RPAP_All_HealthCare_Settings_Eng2. 2012;12

23. Floyd EL, Henry JB, Johnson DL. Influence of facial hair length, coarseness, and areal density on seal leakage of a tight-fitting half-face respirator. J Occup Environ Hyg. 2018;15:334-340. DOI: https://doi.org/ 10.1080/ 15459624.2017.1416388.

24. Mukhtar MS. Mental health and psychosocial aspects of coronavirus outbreak in Pakistan: psychological intervention for public mental health crisis. Asian journal of psychiatry. 2020. DOI: https://doi.org/10.1016/j.ajp.2020.102069.

25. Wong J, Goh QY, Tan Z, Lie SA, Tay YC. Tan Z et al. Preparing for a COVID-19 pandemic: a review of operating room outbreak response measures in a large tertiary hospital in Singapore. Can J Anaesth/J Can Anesth. 2020. DOI: https://doi.org/ 10.1007/s12630-020-01620-9.s 